\title{
Metode VAT untuk meningkatkan kemampuan berbahasa ekspresif tunarungu di Kabupaten Gowa
}

\author{
Cahaya \\ Guru PLB, SLB Negeri Somba Opu \\ Email: cahayaguruslb20@gmail.com.
}

(Diterima: 15-September-2016; direvisi: 10-Oktober-2016; dipublikasikan: 31-Desember-2016)

\begin{abstract}
Abstrak. Objective was to determine (a) the application of the method vibration audio tactile (VAT) in improving language skills expressive deaf students in SLB Somba Opu Gowa, (b) the ability to speak expressively before and after the application of the method vibration audio tactile (VAT) students deaf SLB class VIII in Somba Opu Gowa. This research is a kind of experiment subjects tungal (Sangle Subject Researct). This study design is the type A-B-A. Research subjects SMPLB eighth grade students of the Deaf in SLB Somba Opu Gowa. The collection of data obtained through the test works with deskriktif analysis techniques. The results showed that the implementation of the intervention application of audio tactile vibration method (VAT) could increase the ability of class VIII berbahasaekspresif SMPLB deaf in SLB Somba Opu Gowa. Results obtained at baseline phase 1 (A-1) prior to the application of audio tactile vibration method (VAT), and after application of audio tactile vibration method (VAT) or baseline phase 2 (A-2) obtained by ability level value rises $26 \%$ or $88 \%$ level. The results obtained by the students can be concluded that the application of the method of audio tactile vibration affect the increase in expressive language skills in deaf students in SLB Somba Opu Gowa
\end{abstract}

Keywords: Expressive Language; Audio Tactile Visual Method (VAT).

\begin{abstract}
Abstrak. Penelitian bertujuan untuk (a) Mengetahui gambaran penerapan metode Visual Audio Taktil (VAT) dalam meningkatkan kemampuan berbahasa ekspresif siswa tunarungu di SLB Negeri Somba Opu Kabupaten Gowa, (b) Mengetahui kemampuan berbahasa ekspresif sebelum dan setelah penerapan metode Visual Audio Taktil (VAT) siswa tunarungu kelas VIII di SLB Negeri Somba Opu Kabupaten Gowa. Jenis penelitian ini adalah eksperimen subyek tungal (Single Subject Research). Desain penelitian ini adalah jenis A-B-A.. Subyek penelitian adalah siswa kelas VIII tunarungu berjumlah satu orang lak-laki. Pengumpulan data diperoleh melalui tes perbuatan dengan teknik analisis deskriktif. Untuk mengetahui peningkatan hasil penerapan metode VAT dibuatkan grafik. Hasil penelitian pada fase baseline 1 (A-1) sebelum penerapan metode Visual Audio Taktil (VAT) menunjukkan kemampuan berbahasa ekspresif tunarungu kurang dan setelah penerapan metode Visual Audio Taktil (VAT) atau fase baseline 2 (A-2) kemampuan berbahasa ekspresif siswa tunarungu meningkat. Hasil yang diperoleh sebelum dan setelah penerapan metode VAT menunjukkan adanya perubahan sehingga metode VAT dapat diyakinkan bahwa metode tersebut dapat meningkatkan kemampuan berbahasa ekpresif anak tunarungu di SLB Negeri Somba Opu Kabupaten Gowa
\end{abstract}

Kata kunci, Bahasa Ekspresif; Metode Visual Audio Taktil (VAT)

Copyright $(9) 2017$ Universitas Negeri Makassar. This is an open access article under the CC BY-NC-ND license (http://creativecommons.org/licenses/by-nc-nd/4.0/). 


\section{PENDAHULUAN}

Bahasa memiliki peran penting dalam pengembangan intelektual, sosial, dan emosional siswa dan merupakan penunjang keberhasilan dalam mempelajari semua bidang studi oleh karena itu pembelajaran bahasa diarahkan untuk membantu meningkatkan kemampuan siswa SMPLB-B (tunarungu) untuk berkomunikasi dalam bahasa Indonesia yang baik dan benar, baik secara lisan maupun tulisan dan terutama bahasa lisan atau bahasa ekspresif. Bahasa ekspresif bagi anak tunarungu diperlukan, agar dalam berbicara untuk menyampaikan pikiran dan keinginan berkomunikasi secara oral atau lisan bermakna bagi lawan bicaranya dan bermanfaat dalam kehidupan sehari-hari.

Menurut Sugono (2006: 44) bahwa bahasa lisan atau bahasa ekspresif adalah bahasa yang dihasilkan dengan menggunakan alat ucap (Organ Of Speech) dengan fonem sebagai unsur dasarnya. Bahasa lisan mencakup aspek lafal, tata bahasa (bentuk kata dan susunan kalimat) dan kosa kata.

Kemampuan siswa tunarungu berbahasa lisan atau bahasa ekspresif kurang karena adanya gangguan pendengaran yang mengakibatkan hambatan dalam perkembangan kongnitif dan kesulitan berbicara secara lisan dalam berkomunikasi dengan orang lain. Berkaitan dengan indikator yang diukur yaitu mengucapkan huruf, suku kata dan kata kerja pengucapan fonem kurang jelas, sehingga makna bahasa yang disampaikan secara lisan kurang, sebab anak tersebut mengalami kekakuan organ bicara, dan gagap ketika anak berbicara. Faktor penyebab anak tunarungu kurang mampu berbicara secara lisan atau ekspresif adalah, Faktor eksternal dan internal: 1) Faktor eksternal, yaitu metode yang digunakan guru dalam mengajarkan bahasa selama ini menggunakan metode manual, 2) faktor dari anak itu sendiri, bahwa anak mengalami gangguan bicara akibat dari gangguan pendengaran sehingga sulit dalam berkomunikasi dengan orang lain.

Guru sebagai faktor yang menentukan keberhasilan melalui pendidikan untuk meningkatkan kemampuan siswa tunarungu berbahasa ekspresif sebagaimana yang dikemukakan oleh Sadjaah (2005), maka diterapkan metode Visual Audio Taktil (VAT).

Menurut Gunarti (2008: 135) bahwa "bahasa ekspresif adalah bahasa yang dinyatakan". Untuk menyatakan bahasa secara lisan bagi anak tunarungu mengalami gangguan. Sementara itu gangguan bahasa ekspresif diistilahkan dengan "kesulitan berekspresi dimana anak tunarungu tidak dapat mendengar bahasa karena mengalami gangguan pendengaran sehinga tidak dapat memahami apa yang dikatakan orang lain, sulit baginya untuk menempatkan kata bicara secara bersama-sama untuk membahasnya" (Novan, 2014). Dalam kaitan tersebut diatas (Sunardi \& Sunaryo, 2007) mengungkapkan bahwa bahasa mempunyai dua dimensi. Keterampilan berbahasa aktif atau ekspresif dan keterampilan berbahasa pasif atau reseftif. Dimana kemampuan berbahasa aktif adalah kemampuan seseorang untuk menyatakan pikiran, perasaan, dan kehendak pada orang lain, sedangkan kemampuan bahasa reseftif adalah kemampuan untuk memahami pikiran, perasaan dan kehendak orang lain. Agar anak tunarungu mampu menyatakan pikiran perasaan dan kehendaknya pada orang lain diperlukan kemampuan seorang guru dalam mengajarkan bahasa yaitu penguasaan seorang guru menggunakan seperangkat pengajaran yakni: tehnik, strategi dan metode untuk membangun pengetahuan anak tunarungu agar mampu berbicara menyampaikan pikiran dengan orang lain.

Berbicara termasuk dalam kemampuan bahasa ekspresif. Bromley (Dhieni, 2006: 119) menyatakan kemampuan berbicara merupakan suatu ungkapan dalam bentuk kata-kata. Ada yang bersifat reseptif (dimengerti dan diterima) maupun ekspresif (dinyatakan).

Gordon dan Browne (Dhieni, 2006: 75) menambahkan bahwa, "penguasaan berbahasa ekspresif adalah semakin seringnya anak menyatakan keinginan, kebutuhan, pikiran dan perasaan kepada orang lain secara lisan". Kemampuan berbahasa ekspresif anak tunarungu dapat diperoleh melalui aspek-aspek keterampilan. Menurut Edja Sadjaah (2005: 25) keterampilan bahasa diperoleh melalui: 1) keterampilan menyimak/mendengarkan (listening) skill), 2) keterampilan berbicara (speaking skill), 3) keterampilan membaca (reading skill), dan 4) keterampilan menulis (writing skill). Dari kedua pendapat tersebut dapat disimpulkan bahwa untuk membina kemampuan berbahasa anak tunarungu dapat dilakukan dengan menerapkan keempat keterampilan tersebut. Untuk mengukur kemampuan siswa tunarungu mengucapkan kata 
bentuk kata kerja diterapkan metode Visual Audio Taktil (VAT)

\section{METODE}

Jenis penelitian yang digunakan adalah penelitian eksperimen dengan desain. (Single Subjetc Researcth). Penelitian ini akan mengkaji penerapan metode Visual Audio Taktil (VAT) dalam meningkatkan kemampuan berbahasa ekspresif anak tunarungu. Penelitian ini bertujuan untuk mengetahui besaran perubahan perilaku dengan perlakuan yang diberikan secara berulang-ulang dalam waktu tertentu sehingga stabil (A) dan interverensi dengan waktu tertentu pula hingga selesai secara periodik (B).

Desain penelitian Single Subject Research) (SSR) yang digunakan adalah A-B-A, yaitu desain SSR yang memiliki tiga fase yang bertujuan untuk mempelajari besarnya pengaruh dari suatu perlakuan yang diberikan kepada individu, dengan cara membandingkan kondisi baseline sebelum dan sesudah intervensi.

Desain A-B-A memiliki tiga tahap yaitu $\mathrm{A} 1$ (baseline 1), $\mathrm{B}$ (intervensi), dan $\mathrm{A} 2$ (baseline 2). Adapun tahap-tahap yang akan dilaksanakan dalam penelitian ini yaitu:

A1 (baseline 1) yaitu, mengetahui profil dan perkembangan kemampuan dasar siswa dalam hal ini kemampuan berbahasa ekspresif yang dikuasai oleh siswa sebelum mendapat perlakuan. Subjek penelitian (R) diperlakukan secara alami tanpa pemberian intervensi (perlakuan). Sunanto (2006: 41) menyatakan bahwa "baseline adalah kondisi dimana pengukuran perilaku sasaran dilakukan pada keadaan natural sebelum diberikan intervensi apapun". B (Intervensi), yaitu kondisi subjek (R) penelitian selama diberi perlakuan, dalam hal ini adalah penerapan metode Visual Audio Taktil (VAT). Penerapan metode tersebut dilakukan peneliti bertujuan untuk mengetahui peningkatkan kemampuan berbahasa ekspresif anak tunarungu dalam mengucapkan kata selama perlakuan diberikan.

Sunanto, (2006: 41) menyatakan bahwa "Kondisi intervensi adalah kondisi ketika suatu intervensi telah diberikan dan perilaku sasaran diukur di bawah kondisi tersebut". A2 (baseline 2) yaitu pengulangan kondisi baseline sebagai evaluasi sampai sejauh mana intervensi yang diberikan berpengaruh pada subjek (R).

Variabel penelitian penelitian ini mengkaji dua variabel, yaitu kemampuan berbahasa ekspresif sebagai variabel terikat atau dipengaruhi (variabel dependen) dan metode VAT sebagai variabel bebas atau mempengaruhi (variabel independen).

Untuk menghindari adanya beda penafsiran terhadap variabel penelitian ini, maka perlu didefenisikan secara operasional yaitu:

a. Metode VAT: merupakan intervensi yang dilakukan dalam penelitian yaitu suatu sistem pendekatan metode bina bicara yang digunakan dalam membelajarkan bahasa agar siswa tunarungu mampu memperbaiki kesalahan bunyi fonem dalam mengungkapkan suatu kata atau kalimat baik secara lisan, tertulis khususnya lisan dalam bentuk kata kerja

b. Bahasa ekspresif: merupakan target behavior yaitu, kemampuan siswa tunarungu berbahasa secara lisan yang dijadikan pengukuran melalui penerapan metode Visual Audio Taktil (VAT) dengan memfungsikan seluruh indera yaitu, indra pendengaran, indra penglihatan, indra peraba, dan rasa.

Subyek penelitian ini adalah siswa tuna rungu di SLB B Somba Opu Kabupaten Gowa. Subyek penelitian ini terdiri dari 1 siswa yang profil siswa diuraikan serbagai berikut:

1) Subyek berinisial : $R$

2) Tempat dan tanggal lahir :Sinjai, oktober 2003

3) Jenis kelamin : Laki-Laki

4) Data mengenai kemampuan berbahasa ekspresif yaitu : kemampuan berbahasa ekspresif masih kurang

Moleong (Nurmaya, 2016) teknik pengambilan sumber data dengan mengkhususkan pada subyek yang mengalami masalah yang diteliti. Pengumpulan data dilakukan dengan menggunakan instrumen tes. Instrumen tes yang telah dibuat sebelum dilaksanakan penelitian dilapangan telebih dahulu divalidasi oleh dosen validator yaitu, bapak Drs, Agus Marsidi, M.Si, dan ibu Widya Karmila Sari, S,Pd, M.Si, dengan menilai angket format validasi penelitian tes kemampuan berbahasa ekspresif yang meliputi beberapa aspek yang akan dinilai yaitu, kesesuian petunjuk tes, kesesuain tes dengan indikator, kesesuain tes dengan masalah siswa, kelayakan tes, jumlah item tes, analisis data, dan skala penilaian. Tes yang digunakan adalah tes perbuatan yang diberikan kepada siswa sebelum dan setelah dilakukan intervensi tentang kemampuan siswa 
tuna rungu berbahasa ekspresif yaitu penerapan metode Visual Audio Taktil (VAT). Bentuk tes yang dibuat adalah tes yang dikonstruksi oleh peneliti sendiri dengan jumlah item nomor soal 15 nomor. Tes tersebut terdiri dari tiga item masing-masing setiap item terdiri dari 5 soal tes. Dimana ketiga item tersebut meliputi: 1) melafal huruf kata kerja, 2) mengucapkan suku kata pada kata kerja , dan 3) mengucapkan kata kerja. Skor maksimal dari 15 item nomor soal telah dibuat adalah 68 , dan skor minimal atau terendah adalah 0 . Penilaian dilakukan dengan menceklis angka skor sesuai kemampuan siswa tunarungu dalam mengucapkan kata kerja. Untuk memperoleh gambaran kemampuan berbahasa ekspresif siswa tunarungu kelas VIII di SLB Negeri Somba Opu, terlebih dahulu skor akan dikonversikan kedalam rumus:

$$
\text { Nilai }=\frac{\text { skor yang diperolh }}{\text { skor maksimal }} \times 100
$$

Aunurrakhman (2009)

Hasil pengukuran diintergrasikan kedalam kriteria tingkat penguasaan kemampuan bahasa dengan menggunakan skala empat . Adapun kriteri tingkat penguasaan kemampuan berbahasa ekspresif siswa tunarungu digambarkan dibawah ini;

\section{Tabel 3.3. Kriteria Tingkat Penguasaan Bahasa Ekpresif Tunarungu}

\begin{tabular}{cc}
\hline Tingkat Penguasaan & Kriteria \\
\hline $51-68$ & Mampu \\
\hline $34-50$ & Cukup Mampu \\
\hline $17-33$ & Kurang Mampu \\
\hline $0-16$ & Tidak mampu \\
\hline
\end{tabular}

( Sumber: Aunurrakhman, 2009: 39)

Kriteria tersebut diatas ditetapkan melalui hasil perhitungan skor skala empat. Kriteria absolut (sumber ideal) digunakan untuk mengukur keberhasilan tindakan apakah hasil tindakan mendekati kriteia, mampu, cukup mampu, kurang mampu ataupun tidak mampu. Jumlah soal 15 dengan skor maksimal adalah 68, dan skor minimal adalah 0 .

\section{HASIL DAN PEMBEHASAN}

$\begin{array}{ccll} & \text { Penelitian ini dilaksanakan di } & \text { SLB } \\ \text { Somba Opu Kabupaten Gowa guna }\end{array}$ memperlihatkan adanya peningkatan kemampuan berbahasa ekspresif melalui penerapan metode Visual Audio Taktil (VAT). Pengukuran penelitian dilakukan dua kali yaitu sebelum dan setelah pelaksanaan intervensi.

Pelaksanaan penelitian jenis eksperimen subyek tunggal Single Subject Research (SSR) terdiri dari tiga tahap yaitu:

1) A1 (baseline 1) yaitu, mengetahui profil dan kemampuan dasar siswa dalam hal ini kemampuan berbahasa ekspresif yang dikuasai oleh siswa sebelum mendapat pelakuan. Tes kemampuan berbahasa ekspresif yang diukur terdiri atas tiga aspek yaitu: aspek melafalkan huruf, mengucapkan suku kata, dan kata kerja. Dan setiap aspek terdiri atas 5 nomor soal. Jumlah skor seluruhnya dari 15 item nomor soal adalah 68 .

2) B (intervensi), yaitu kondisi subjek selama diberi perlakuan yaitu penerapan metode Visual Audio Taktil (VAT) yang bertujuan untuk mengetahui gambaran peningkatkan kemampuan berbahasa ekspresif anak tuna rungu dalam mengucapkan kata selama perlakuan diberikan. Sunanto, (2006: 41) menyatakan bahwa "kondisi intervensi adalah kondisi ketika suatu intervensi telah diberikan dan perilaku sasaran diukur di bawah kondisi tersebut."

3) A2 (baseline 2), yaitu pengulangan kondisi baseline sebagai evaluasi sampai sejauh mana kemampuan siswa terhadap pelaksanaan intervensi yang diberikan apakah berpengaruh terhadap peningkatan kemampuan berbahasa ekspresif pada subjek yang dilakukan penilaian. Data hasil penelitian terhadap kemampuan siswa tunarungu berbahasa ekspresif sebelum dan setelah intervensi dianalisis secara deskriptif dan divisualisasikan melalui dan grafik batang. 
Adapun gambaran hasil penelitian kemampuan siswa tunarungu berbahasa ekspresif melalui penerapan Metode Visual Audio Taktil

(VAT) dalam dapat dilihat dibawah ini

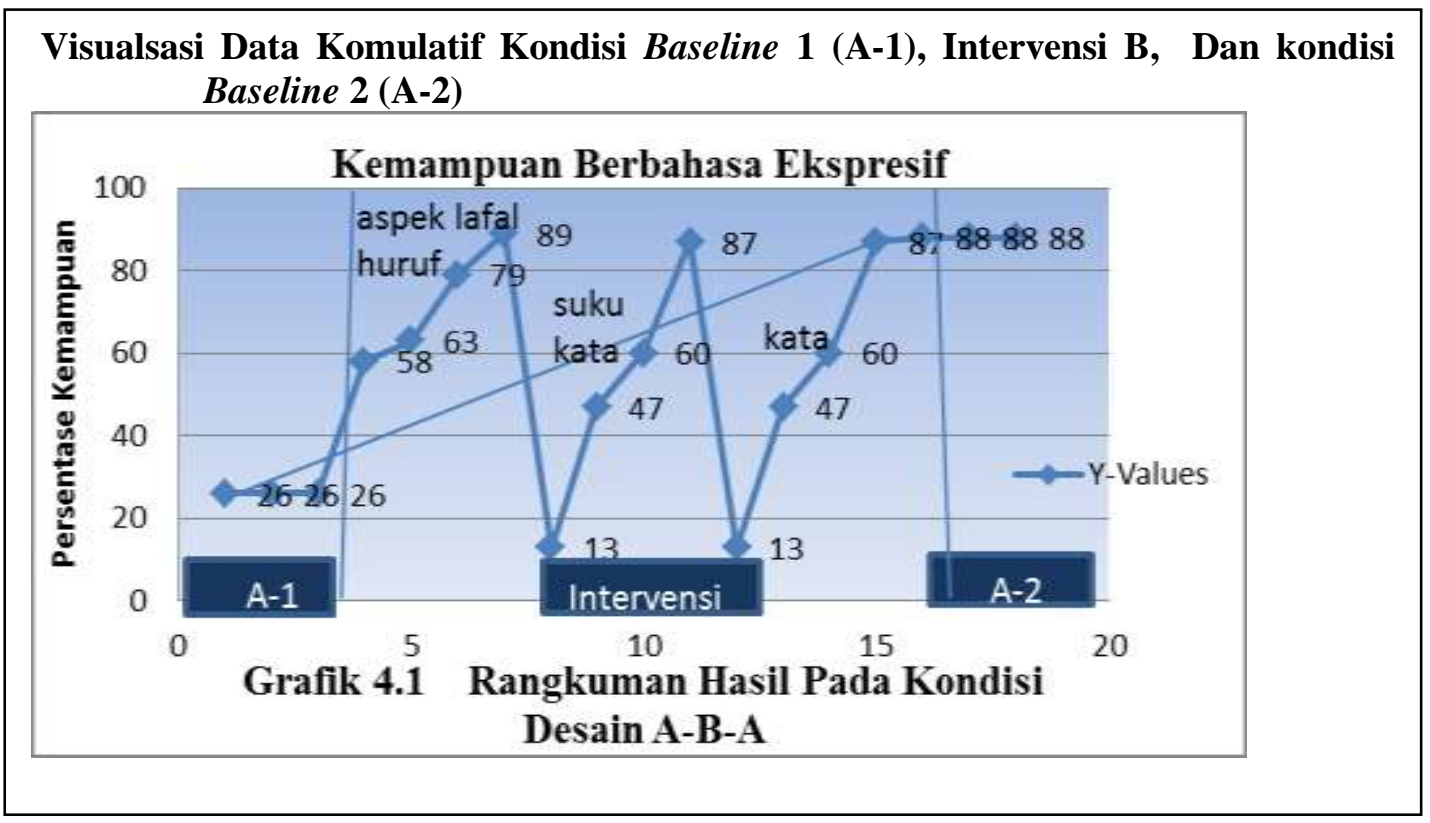

Data grafik kemampuan berbahasa ekspresif tersebut di atas menunjukkan bahwa, hasil yang diperoleh dari tiga sesi tes diberikan rata-rata diperoleh kemampuan $26 \%$, dan setelah penerapan metode VAT diperoleh kemampuan rata-rata $88 \%$ dari tiga sesi diberikan. Hasil yang diperoleh sebelum dan setelah penerapan metode VAT menunjukkan adanya perubahana. Besarnya perubahan level adalah $62 \%$ yaitu hasil dari $88 \%-26 \%$

Berdasarkan rangkuman hasil data kemampuan kondisi baseline 2 (A-2) menunjukkan kemampuan diberi simbol (+) mendatar dan efek meningkat.

Salah satu hasil penelitian membuktikan (Suparno, 2003) bahwa kecakapan artikulasi anak tunarungu dapat meningkat melalui penerapan metode Visual Audio Taktil (VAT). Hasil yang diperoleh mencapai nilai $86 \%$. Demikian juga hasil penelitian yang dilakukan membuktikan bahwa kemampuan yang diperoleh siswa tunarungu mengucapkan kata kerja

Tabel: 4.1 Kecenderungan Jejak Data Kemampuan Berbahasa Ekspresif

\begin{tabular}{cccc}
\hline Kondisi & A-1 & Intervensi & A-2 \\
\hline $\begin{array}{c}\text { Jejak Data } \\
\text { (Data Path) }\end{array}$ & $-\overline{\text { (-) }}$ & $(+)$ \\
\hline
\end{tabular}

berbahasa ekpresif pada kondisi baseline A-1, Intervensi, dan baseline A-2 seperti telihat pada grafik di atas di bawah ini akan digambarkan jejak kecenderungan arah.

Berdasarkan tabel 4.1 tersebut di atas hasil penelitian menunjukkan, kemampuan pada kondisi baselane 1 (A-1) setiap sesi diperoleh simbol mendatar (-) dengan nilai rata-rata kurang dan setelah dilakukan intervensi yaitu pada mencapai " $88 \%$. Sehingga dengan demikian dapat disimpulkan bahwa metode Visual Audio Taktil (VAT) diyakinkan kebenarannya bahwa metode tersebut berpengaruh besar terhadap kemampuan siswa tuna rungu mengucapkan kata kerja atau berbicara secara lisan.

Berdasarkan hasil pengamatan observasi melalui proses pembelajaran nilai yang diperoleh siswa tunarungu mengalami peningkatan, bahwa pada pelaksanaan intevensi yaitu penerapan metode Visual Audio Taktil (VAT) siswa 
tersebut mampu: 1) Meniru melafalkan fonem dengan benar pada kata kerja yang dilakukan pengukuran, 2), Pengucapan suku kata sesuai kaidah bahasa, 3) Mampu mengucapkan kata sesuai isi cerita terhadap media yang telah di pajang, 4) Mampu memperbaiki kesalahan terhadap pengucapan kata kerja, 5) Bahasa yang diungkapkan sudah dapat dipahami, 6) Mendemonstrasikan kata kerja sudah benar, 7) Mampu mengekspresifkan simbol bahasa kedalam konsep tulis, 8) Irama bicara anak mendekati normal, 9) Intonasi bicara dalam mengungkapkan kata kerja sudah jelas, 10) Mengucapkan kata kerja mendekati idealnya.

Menurut Sunantio, J, et al (2006) simbol tersebut menunjukkan data stabil bahwa, sebelum pelaksanaan intervensi data tersebut kurang dan setelah intervensi data tersebut meningkat. Untuk membandingkan hasil sebelum dan setelah pelaksanaan intervensi yaitu penerapan metode Visual Audio Taktil (VAT) pada penjelasan sebelumnya, bahwa hasil yang diperoleh kedua kondisi tersebut digambarkan diagram batang. Adapun grafik diagram batang seperti gambar berikut.

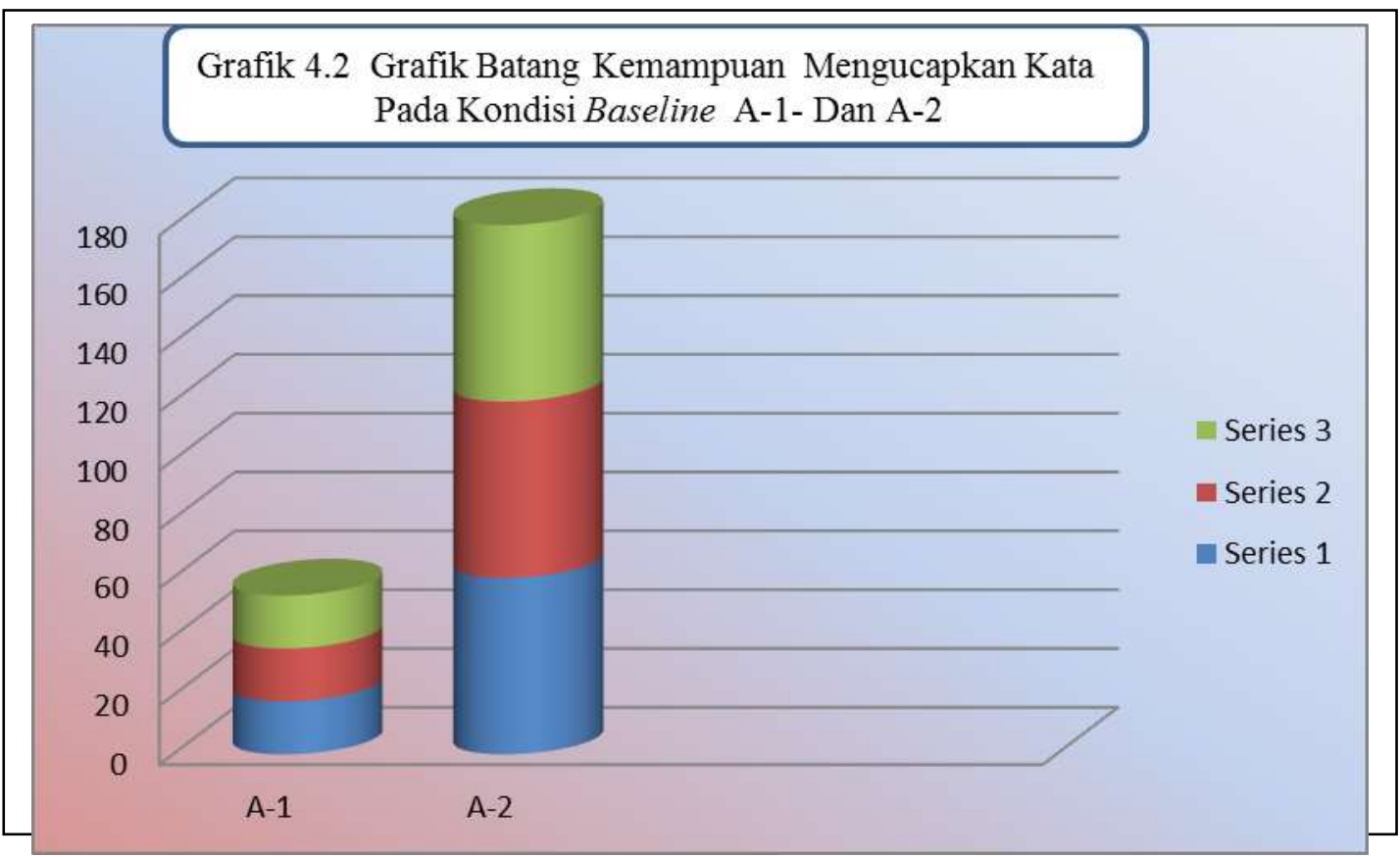

Berdasarkan data diagram batang tersebut di atas menunjukkan bahwa skor yang diperoleh pada setiap sesi tes diberikan, kemampuan siswa rata-rata diperoleh skor " 18 " pada kondisi baseline A-1. Dan pada kondisi baseline A-2, diperoleh skor "60" pada setiap sesi. Sehingga skor kemampuan siswa naik pada level "42". Agar penilaian tersebut lebih reliabel, maka dapat direalisasikan ke dalam kriteria tingkat penguasaan bahasa seperti ditampilkan pada BAB III.

Berdasarkan kriteria tingkat penguasaan bahasa ekspresif siswa tunarungu seperti tercantum pada BAB III dengan perolehan skor rata-rata setiap sesi pada kondisi A-1 adalah " 18 " dikategorikan kurang dengan persentase kemampuan "26\%". Dan pada kondisi A-2 perolehan skor rata rata-rata setiap sesi adalah "60" dikategorikan mampu dengan persentase alam kriteria tingkat penguasaan bahasa sebagamana ditampilkan pada BAB III. persentase kemampuan " $88 \%$ ". Dalam penelitian Single Subject Researc (SSR), (Sunanto, 2006) mengatakan bahwa, apabila sudah mencapai nilai 80-90\% dikatakan mampu. Dengan demikian ditarik kesimpulan bahwa hasil penelitian sebelum dilakukan intervensi diperoleh skor kurang yaitu "18" dan setelah dilakukan intervensi diperoleh skor meningkat yaitu "60". Skor 60 berada pada skala interval kategori mampu, dengan selisih kenaikan skor"42"

Berdasarkan hasil analisis data kemampuan berbahasa ekspresif terhadap penerapan metode Visual Audio Taktil (VAT) pada siswa SMPLB tunarungu kelas VIII di SLB Negeri somba Opu Kabupaten Gowa diperoleh pada baseline 1 (A-1) setelah dilakukan tes diperoleh skor hasil skor rata-rata "18". Skor tersebut tidak memenuhi kriteria $80 \%$ Untuk 
meningkatkan kemampuan berbahasa ekspresif siswa SMPLB-B (Tunarungu) diterapkan metode Visual Audio Taktil VAT), karena bahasa ekspresif diperlukan bagi anak tunarungu agar dalam berbicara untuk menyampaikan pikiran dan keinginan berkomunikasi secara oral atau lisan bermakna bagi lawan bicaranya dan bermanfaat dalam kehidupan sehari-hari.

Menurut Sugono (2006: 44) bahwa: Bahasa lisan atau bahasa ekspresif adalah bahasa yang dihasilkan dengan menggunakan alat ucap (Organ Of Speech) dengan fonem sebagai unsur dasarnya". Bahasa lisan mencakup aspek lafal, tata bahasa (bentuk kata dan susunan kalimat), dan kosa kata.

Guru selama ini membelajarkan bahasa lisan tidak menerapkan metode Visual Audio Taktil (VAT). Metode yang digunakan mengajar selama ini adalah metode manual. Untuk meningkatkan potensi yang dimiliki anak tuna rungu dalam berbahasa ekspresif (Sadjaah, 2005), maka diterapkan metode Visual Audio Taktil (VAT).

Dwidjosumarto (Purwanti: 2014) mengemukakan tuna rungu dapat diartikan sebagai "suatu keadaan kehilangan pendengaran yang mengakibatkan seseorang tidak dapat menangkap berbagai perangsang terutama melalui indera pendengaran". Konsep tersebut agar kemampuan mendengar dapat difungsikan perlu adanya umpan balik auditoris pada waktu ia bersuara. Anak tidak dapat menangkap rangsangan melalui pendengaran karena tidak cukup menerima penguat dari orang dewasa, serta model bahasa atau bina bicara orang dewasa. Untuk memberikan rangsangan pendengaran fungsi penglihatan anak tunarungu difungsikan sehingga nantinya anak mampu mengucapkan.

Hasil analisis kemampuan awal atau fase baseline 1 yang di simbol dengan A-1 menunjukkan bahwa kemampuan yang diperoleh siswa berinisial " $R$ " skor rata-rata diperoleh " 18 " dari skor maksimal " 68 ", dengan persentase kemampuan "26\%". Melalui penilaian kemampuan siswa tunarungu mengucapkan kata kerja sebagaimana dideskripsikan setiap item penilaian yang telah dikonseptualkan pada hasil penelitian rata-rata kurang. Untuk meningkatkan kemampuan siswa tunarungu mengucapkan kata kerja pelaksanaan intervensi (B) dilakukan dengan menerapkan metode Visual Audio Taktil (VAT). Hasil skor yang diperoleh setelah penerapan metode tersebut kemampuan siwa tunarungu mengucapkan kata meningkat menjadi " 60 " atau " $88 \%$. Selisih perubahan skor naik dari " 18 " dengan persentase " $26 \%$ " naik menjadi "60", dengan persentase " $88 \%$ ". Sehingga selisih kenaikan skor " 42 " dan persentase "62\%".

Melalui grafik batang tersebut di atas menunjukkan bahwa, skor kemampuan siswa tunarungu pada fase baseline 1 (A-1) diperoleh kurang, dan pada fase baselane 2 (A-2) skor atau hasil yang diperoleh dapat dikategorikan mampu.

Dengan demikian dapat disimpulkan bahwa dengan diterapkannya metode Visual Audio Taktil (VAT) terbukti dapat meningkatkan kemampuan berbahasa ekspresif siswa SMPLB tunarungu di SLB Negeri Somba Opu Kabupaten Gowa

\section{SIMPULAN DAN SARAN}

Hasil penelitian mengenai penerapan metode Visual Audio Taktil (VAT) dalam meningkatkan kemampuan berbahasa ekspresif siswa tunarungu di SMPLB Negeri Somba Opu disimpulkan sebagai berikut:

Metode Visual Audio Taktil (VAT) sebagai metode bina bicara diterapkan untuk memperbaiki pengucapan siswa tunarungu dengan memfungsikan seluruh sensori atau indra yaitu: indra, "penglihatan", "pendengaran", "rasa", dan "raba". Sensori tersebut dideskripsikan: a) sensori "melihat" siswa memperhatikan alat bicara yang dibentuk atau melihat ucapan guru kemudian mencontohkannya, b) "mendengar", mendengar apa yang diucapkan guru dengan cara melihat anak menirukannya c) "merasakan" untuk merasakan getaran getaran suara, tangan diletakkan pada bagian-bagian tubuh tertentu agar siswa merasakan getaran getaran suara tersebut yang ditimbulkan melalui perabaan. Misalnya fonem "A" diletakkan di leher bagian bawah dagunya atau dagu guru, bisa ditempelkan di mulut, fonem "M" diletakkan di pipi. Sebelum pelaksanaan intervensi kemampuan berbahasa ekspresif siswa tunarungu kurang, dan setelah pelaksanaan intervensi kemampuan berbahasa ekspresif siswa tunarungu meningkat. Kemampuan berbahasa ekspresif tuna rungu menunjukkan kelebihan metode VAT dalam proses, sebab guru bersentuhan langsung dengan fisik anak tuna rungu dalam memberikan model pengajaran memperabakan tangan pada bagian wajah tertentu dalam membentuk atau 
memperbaiki pengucapan fonem kata kerja. Dan akan menjadi kelemahan metode VAT jika melalui proses guru kurang terampil menerapkannya. Hasil penerapansebelum dan setelah penerapan metode Visual Audio Taktil (VAT), menunjukkan dapat meningkatkan kemampuan berbahasa ekspresif siswa tunarungu.

Dengan demikian hasil penelitian ini dapat menjawab rumusan masalah peneitian bahwa penerapan metode Visual Audio Taktil (VAT) dapat meningkatkan kemampuan barbahasa ekspresif anak tunarungu. Sehubungan kesimpulan penelitian di atas, maka dapat diajukan saran-saran sebagai berikut: Peneliti berharap hasil penelitian ini dapat dijadikan acuan atau referensi untuk mengkaji lebih dalam tentang penerapan metode Visual Audio Taktil (VAT) dalam meningkatkan kemampuan berbahasa ekpresif siswa tuna rungu, a) Bagi sekolah khususnya SLB Negeri Somba Opu Kabupaten Gowa bahwa pembelajaran dengan menggunakan metode Visual Audio Taktil (VAT) dapat dijadikan sebagai salah satu alternatif dalam meningkatkan kemampuan berbahasa lisan bagi siswa tuna rungu. b) Kepada guru di sekolah, sebagai masukan dalam membelajarkan bahasa lisan kepada anak tunarungu melalui proses diterapkan metode Visual Audio Taktil (VAT)

\section{DAFTRAR RUJUKAN}

Aunurrakhman, (2009). Perkembangan Peserta Didik. Direktorat Jenderal Endidikan Tinggi Depertemen Pendidikan Nasional
Dhieni, (2006). Metode Pengembangan Bahasa. Jakarta: Universitas Terbuka.

Gunarti, (2008). Metode Pengembangan Perilaku dan Kemampuan Anak Usia Dini. Jakarta: Depdiknas.

Nurmaya, Alya. (2016). Penyalahgunaan Napza di Kalangan Remaja (Studi Kasus pada 2 Siswa di MAN Bima). Jurnal Psikologi Pendidikan dan Konseling. 2 (1). 26-32.

Novan, (2014). Penanganan Anak Usia Dini Berkebutuhan Khusus. Jakarta.

Purwanti, Tri. (2014). Peningkatan Pengendalian Diri Melalui Modifikasi Perilaku pada Anak Tunarungu Di Kelas c TKLB SLB Negeri 2 Bantul. Yogyakarta: Skripsi. Tidak diterbitkan. Fakultas Ilmu Pendidikan.

Sadjaah, E, (2005). Modul Pengembangan Pendidikan Dan Profesi Guru Rayon 124. Makassar: Direktorat Pendidikan Dan Kebuayaat.

Sugono, (2006). Metode Pengembangan Bahasa. Jakarta: UniversitasTerbuka.

Sunanto, J, (2006). Pengantar Penelitian Dengan Subyek Tunggal, Criced Universit: Tsukuba.

Sunardi \& Sunaryo, (2007). Intervensi Dini Anak Berkebutuhan Khusus. Depertemen Pendidikan Nasional. Direktorat Jenderal Pendidikan Tinggi.

Suparno, (2003). Upaya meningkatkan Kecakapan Artikulasi Anak Tuna Rungu, Model Metode VAT. Yogyakarta: Jurnal Kajian Artikulasi. 